Egypt. J. of Nutrition and Health Vol. 15 No. 1 January (2020)

\title{
Effect of Some Medicinal Plant Seeds on CCI4 -Induced Hepatotoxicity in Experimental Rats
}

\author{
Samah A. El-Hashash, Amira M. EIMoslemany \\ and Amany A. Abd El-Mageed \\ Nutrition and Food Science Dept., Faculty of Home Economics \\ Al-Azhar University,Egypt
}

\begin{abstract}
There are many plants which are used as medicinal plants by many people such as purslane, chia and garden cress. The present study was carried out to investigate the effect of purslane, chia and garden cress seed powders on $\mathrm{CCl}_{4}$-induced hepatotoxicity in experimental rats. Rats were randomly assigned to 2 main groups including normal or negative control group (6 rats) which fed on basal diet only for 6 weeks, and injected group (36 rats) which injected subcutaneously with $\mathrm{Ccl}_{4}$ in paraffin oil( $50 \% \mathrm{v} / \mathrm{v}, 2 \mathrm{ml} / \mathrm{kg}$ body weight) twice a week for two weeks to induce chronic damage in liver. After induction, rats were divided into 5 equal groups including positive control group which fed on basal diet only besides 4 herbs -treated groups which fed on basal diet supplemented with $5 \%$ of either dry purslane, chia,garden cress seed powders or their mixture,respectively. The curative periodcontinued for 4 weeks. By its end, body weight gain and relative weights of some internal organs were calculated. In addition, serum and liver tissue homogenates were biochemically analyzed. The obtained results revealed that $\mathrm{Ccl}_{4}$ exposure led to liver and kidney dysfunction and induced hyper lipidemia due to its oxidative effect. As a result of their antioxidant and phenolic compound contents, using purslane, chia and garden cress seed powders singly or as a mixture improved liver and kidney functions and induced hypolipidemic effect.So, patients who suffer from hepatotoxicity as result of $\mathrm{CCl}_{4}$ exposure can use these plant seeds to test their possible efficiency for their condition.
\end{abstract}

Key words: Hepatotoxicity, $\mathrm{CCl}_{4}$, purslane seeds, chia seeds, garden cressseeds, phenolic compounds, rats

\section{Introduction}

Liver is the largest organ of the human body weighing approximately $1500 \mathrm{~g}$, and is located in the upper right corner of the abdomen on top of the stomach, right kidney and intestines and beneath the diaphragm. The liver performs more than 500 vital metabolic functions (Naruseet al.,2007). including the synthesis of glycogen, plasma proteins, clotting factors bile, urea, etc. (Saukkonenetal., 2006).

The liver disorders are one of the serious health problems,throughout the world. More than 350 million people were affected with chronic hepatic infections worldwide (Salhab and Canelo, 2011). Hepatotoxicity refers to liver dysfunction or liver damage that is associated with an overload of drugs or xenobiotics (Navarro and Senior2006).

Carbon tetrachloride $\left(\mathrm{CCl}_{4}\right)$ is widely used for experimental induction of liver injury. The injury produced depends on $\mathrm{Ccl}_{4}$ metabolism to a highly reactive of free radicals which initiate lipid peroxidation. 


\section{Samah A. El-Hashash, et al}

Antioxidant agents of natural origin have attracted special interest because they can protect from free radical. Numerous medicinal plants and their formulation are used for liver disorders in ethnomedical practices as well as intraditional medicine.(Parolaet al.,1992)

Portulaca oleracea L. (POL), commonly known as purslane, is listed in the World Health Organization as one of the most used medicinal plants and it has been given the term 'Global Panacea' (Isinet al., 2007). POL, as "vegetable for long life" in Chinese folklore, has a cosmopolitan distribution and widely used in many countries (Jinet al., 2013). Modern studies have shown that POL was a rich source of linolenic acid (LNA) and a-tocopherol ( $\alpha$-TCP) (Teixeira et al., 2010). POL exhibited a wide range of pharmacological effects such as anti-inflammatory (Chan et al., 2000), antibacterial (Zhang et al., 2002), skeletal muscle relaxant (Parry et al., 1993), stomach and mouth ulcers (Karimi et al., 2004), diabetic complications (Lee et al., 2012) and liver injuries (Liu et al., 2015).

Chia (Salvia hispanicaL.) is an annual herbaceous plant which is native to southern Mexico and northern Guatemala (Ayerza and Coates, 2011; Capitaniet al., 2012). In recent years, chia seeds have been included in the human diet due to the health benefits associated with their composition Ixtainaet al., (2011).According to Marineliet al. (2014), chia has been investigated and recommended for use due to its high nutritional value. It also contains a high number of antioxidants. Moreover, heavy metal analysis showed that chia seed contains them at safe levels, not exceeding the maximum metal levels for food safety, and the seed is also free from mycotoxins (Tetens, 2009). However, high percentage of fatty acids which are beneficial to health (mainly $\omega$-3 PUFAs, especially $\alpha$-linolenic acid) is the major cause behind the deep recommendations for use of chia seeds in supplementing commercial human diets (Cooreyet al. 2012).

Lepidium sativum L. (Brassicaceae), a medicinal plant origin in Egypt and Middle East, is now cultivated in whole world and often referred to as garden cress. Lepidium sativum $\mathrm{L}$. is used as remedy for inflammatory diseases, such as diabetes, arthritis, traumatic injuries, and hepatitis in traditional medicine (Bigoniya and Shukla, 2014). The extract of Lepidium sativum L. is reported to have various in vitro biological effects including antioxidant, anti-inflammatory, antidiarrheal, antimicrobial, antispasmodic and hepatoprotective action against oxidative damage and have a great potential for use as herbal hepatoprotective or dietary supplements (Del Valle Mendozaet al., 2014; Al-Sheddiet al., 2016).The present investigation was carried out to evaluate the effect of purslane, chia and garden cress seeds powder on hepatotoxicity induced by carbon tetra chloride $\left(\mathrm{CCL}_{4}\right)$ in experimental rats.

\section{Materials and Methods}

Materials:

Dry seeds of purslane (Portulaca oleracea L.), chia (Salvia hispanica L.) and garden cress (Lepidium sativum L.) were purchased from Arab company for Pharmaceutical and Medicinal plants, MEPACO, Egypt. A total of 42 adult male albino rats (Sprague_Dawley strain) were obtained from the animal colony, Helwan farm, Vaccine and Immunity Organization, Ministry of Health, Cairo Governorate, Egypt All required chemicals were obtained from Elgomhouria Company for Trading Drugs, Chemicals and Medical Appliances, Cairo, Egypt.

Casein, Vitamins mixture and salt mixture: Were purchased from El-Gomhoria Company, Cairo, Egypt. 


\section{Egypt. J. of Nutrition and Health Vol. 15 No. 1 January (2020)}

Methods:

Chemical analysis of seeds

Phenolic compounds in seed powders were identified and determined by HPLC according to Goupy et al., (1999).

\section{Experimental animal}

Forty-two mature white Albino rats of an average body weight $150 \pm 10 \mathrm{~g}$ of Sprague Dawley Strain wasused... Rats were fed on basal ration supplying the essential vitamins and trace elements and water supply was given ad-libitum

\section{Preparation of Experimental diet}

Basal diet was prepared from fine ingredient per $100 \mathrm{~g}$ as follows:lt had the following composition: Casein ( $\geq 80 \%$ protein) $14 \%$, soybean oil $4 \%$,cellulose $5 \%$, mineral mixture $3.5 \%$, vitamin mixture $1 \%$, cholinechloride $0.25 \%$, DL-methionine $0.3 \%$ and corn starch up to $100 \mathrm{~g}$ (Reeves et al., 1993)

\section{Experimental design}

Rats were divided into 2 main groups as follows:

The first main group (6 rats): normal rats were fed on basal diet only as a negative control group for six weeks. The second main group (36rats): normal rats were injected subcutaneously with $\mathrm{CCl}_{4}$ in paraffin oil(50\% v/v, $2 \mathrm{ml} / \mathrm{kg}$ body weight)twice a week for two weeks to induce chronic damage in the liver (Jayasekharet al., 1997).Six rats were Slaughtered after injection (at the end of two weeks) to ensure of liver injury. AST and ALT were determined to ensure the induction, then the injected remaining rats divided into 5 equal groups as follows:The second injected group(6 rats):were fed on basal diet only for 4 weeks as a positive control group. The third injected group(6 rats):were fed on basal diet supplemented with $5 \%$ dry purslane seeds for 4 weeks. The fourth injected group (6 rats):were fed on basal diet supplemented with $5 \%$ dry chia seeds for 4 weeks. The fifth injected group (6 rats):were fed on basal diet supplemented with $5 \%$ dry garden cress seeds for 4 weeks. The sixth injected group (6 rats):were fed on basal diet supplemented with the three dry seeds as a mixture (5\%)for 4 weeks which were taken (5\%) from each seeds and the mixture taken (5\%) Body weight and feed intake were checked once a week. At the end, animals were weighed, fasted overnight, and then sacrificed under very light ether anaesthesia.

\section{Biological evaluation}

At the end of the experiment, feed intake, body weight gain, relative organs weight and feed efficiency ratio were calculated according to Chapman et al., (1959)

\section{Biochemical analysis of serum:}

After sacrifice of rats, Blood samples were collected from hepatic portal vein of each rat into dry clean centrifuge tubes. Serum was carefully separated by centrifugation of blood samples at 3500 round per minute (rpm)for 15 minutes at room temperature, transferred into dry clean ebendorf tubes, then kept frozen at $-20^{\circ} \mathrm{C}$ for later determinations.

Serum AST and ALT were determined in the serum according to the method described by Reitman and Frankel (1957). Serum albumin was determined according to Drupt (1974).Serum globulin was calculated according to the equation described by Chary and Sharma (2004). Malondialdehyde (MDA) was carried according to Sushmakumariet al., (1989) 


\section{Samah A. El-Hashash, et al}

Lipid peroxidation was estimated according to the method of (Ohkawaet al., 1979). Nitric oxide was followed as the method reported by Green et al.,(1982). Uric acid was determined in the serum according to the method described by Fossati et al., (1980).Urea nitrogen was determined in the serum according to the method described by Patton et al.,(1977).Creatinine forms colored complex when react with alkaline Picrate. This reaction described by Faulkner and King (1976).

Total cholesterol was determined in the serum according to the method described by Allain et al., (1974). Triglycerides were determined in the serum according to the method described by Trinder and Ann (1969). HDL-C was determined in the serum according to the method described by LopesVirella et al., (1977). Serum VLDL-C was calculated by the following equation: VLDL-C= Triglyceride/5 according to Friedwaldet al., (1972).Serum LDL-C was calculated by the following equation: LDL-C = Total cholesterol - (HDL-C + VLDL-C) according to Friedwaldet al., (1972).

\section{Organ sampling:}

Livers and kidneys were removed from rats by careful dissection, washed in saline solution $(0.9 \%)$, dried using filter paper and independently weighed. A specimen from each organ was kept at $(-800 \mathrm{C})$ for preparation of tissue homogenate for determination of antioxidant parameters. The homogenation was centrifuged at 1000 r.p.m for 10 minutes.

\section{Statistical analysis:}

Statistical analysis were carried out using one-way analysis of variance(ANOVA) test followed by Duncan test through the program of statistical packages for the social science (SPSS). Results were expressed as mean \pm SD. The differences among means at $p<0.05$ were considered significant (Snedecor and Cochran, 1989)

\section{Results}

\section{Phenolic compounds of seeds $(\mu \mathrm{g} / 100 \mathrm{~g})$ by HPLC analysis}

Purslane, chia,and garden cress seeds analyzed for their phenolic Compounds. The obtained results showed in table (1): purslane seeds recorded higher content of Protocatechuic, and catechol than garden cress and chia seeds. Purslane seeds recorded lower content of Gallic, 4-Amino benzoic, Caffeine, P-OH benzoic, Caffeic, Ellagic, P-Coumaric,3,4,4-Methoxy-cinnnamic and Coumarin than garden cress and chia seeds.

While Chia seeds recorded higher content of Caffeic,Vanillic,Ferulic, Salicylic, 3,4,5-methoxycinnamic, Coumarin, and Cinnamic than purslane and garden cress seeds. and recorded lower content of Chlorogenic than purslane and garden cress seeds.

Garden cress recorded higher content of Gallic, Pyrogallol, 4-Aminobenzoic, Catechin, Chlorogenic, Caffeine, P-Coumaric,Ellagic, Benzoic than purslane and chia seeds. and recorded lower content of Protocatechuic,Catechol, Salicylic and Cinnamic than purslane and chia seed. 
Egypt. J. of Nutrition and Health Vol. 15 No. 1 January (2020)

Table (1)

Phenolic compounds of chia, purslane and garden cress seeds $(\mu \mathrm{g} / 100 \mathrm{~g})$

\begin{tabular}{|c|c|c|c|c|}
\hline \multirow{2}{*}{ Phenolic compounds } & \multirow{2}{*}{ Test Methods } & \multicolumn{3}{|c|}{ Phenolic compounds $(\mu \mathrm{g} / 100 \mathrm{~g})$} \\
\hline & & Chia Seeds & Purslane seeds & Garden Cress Seeds \\
\hline Gallic acid & \multirow{21}{*}{ से } & 34.20 & 15.54 & 56.94 \\
\hline Pyrogallol & & 476.88 & 332.11 & 732.43 \\
\hline 4-Aminobenzoic & & 10.71 & 5.42 & 11.40 \\
\hline Protocatchuic & & 64.45 & 69.36 & 38.22 \\
\hline Catechein & & 104.34 & 124.28 & 312.05 \\
\hline Chlorogenic & & 29.52 & 33.37 & 76.37 \\
\hline Catechol & & 36.36 & 66.43 & 33.04 \\
\hline Caffeine & & 49.62 & 38.82 & 81.19 \\
\hline p-OH-benzoic & & 55.88 & 19.95 & 55.44 \\
\hline Caffeic & & 12.11 & 4.37 & 7.22 \\
\hline Vanillin & & 42.52 & 24.72 & 24.12 \\
\hline p-coumaric & & 9.23 & 6.02 & 20.94 \\
\hline Ferulic & & 15.11 & 10.74 & 11.08 \\
\hline Iso- ferulic & & 60.0 & - & 22.71 \\
\hline Ellagic & & 117.56 & 106.36 & 122.06 \\
\hline Alpha-coumaric & & 1.35 & 0.97 & 1.33 \\
\hline Benzoic & & 94.77 & 70.23 & 211.88 \\
\hline salycillic & & 128.14 & 85.47 & 77.69 \\
\hline 3,4,5-methoxy-cinnamic & & 46.25 & 5.28 & 28.66 \\
\hline Coumarin & & 24.20 & 13.81 & 15.60 \\
\hline cinnamic & & 18.85 & 3.61 & 4.94 \\
\hline
\end{tabular}

\section{Biological evaluation:}

\section{Nutrition evaluation:}

Data presented in Table (2) showed the effect of feeding Purslane,Chia, Garden Cress, and their Mixture on feed intake, body weight gain and feed efficiency ratio in $\mathrm{CCl}_{4}$-intoxicated rats. It could be noticed that the (+ve) control group recorded a significant decrease in feed intake ,body weight gain and feed efficiency ratio compared with the $(-v e)$ control group $(p<0.05)$. All seed- treated group recorded a significant increase compared with (+ve) control group, but they couldn't return three parameters toward its normal value recorded by (-ve)control group. Feeding mixed seeds improved the three parameters to value near the (-ve) control group .

Table (2)

Effect of feeding Purslane,Chia, Garden Cress seeds, and Seeds mixture on feed intake, body weight gain and feed efficiency ratio in rats

\begin{tabular}{|c|c|c|c|c|}
\hline \multicolumn{2}{|c|}{$\begin{array}{ll}\text { Groups } & \text { Parameters } \\
\end{array}$} & $\mathrm{FI}$ (g/28 day) rat & BWG \% & FER \% \\
\hline \multicolumn{2}{|r|}{ (-ve) control } & $505 \pm 11.80^{\mathrm{a}}$ & $36.40 \pm 2.30^{\mathrm{a}}$ & $.0981 \pm .004^{\mathrm{a}}$ \\
\hline \multirow{5}{*}{$\begin{array}{l}00 \\
0 \\
0 \\
0 \\
0 \\
0 \\
0 \\
\stackrel{0}{0} \\
\stackrel{0}{\Xi} \\
0 \\
0 \\
0\end{array}$} & (+ve) control & $351.60 \pm 8.03^{\mathrm{c}}$ & $16 \pm 1.30^{d}$ & $.070 \pm .006^{c}$ \\
\hline & Purslane Seeds (5\%) & $487.40 \pm 5.30^{\mathrm{b}}$ & $25.30 \pm 1.90^{\mathrm{C}}$ & $.081 \pm .007^{b}$ \\
\hline & Chia Seeds (5\%) & $487 \pm 5.20^{\mathrm{b}}$ & $26.40 \pm 1.70^{\mathrm{c}}$ & $.078+015^{\mathrm{cb}}$ \\
\hline & Garden Cress Seeds (5\%) & $484.50 \pm 7.10^{\mathrm{b}}$ & $24.90 \pm 2.05^{\mathrm{c}}$ & $.081 \pm .006^{\mathrm{b}}$ \\
\hline & Seed mixture & $507.90 \pm 8.80^{\mathrm{a}}$ & $30.30 \pm 1.70^{b}$ & $.094_{ \pm} .004^{\mathrm{a}}$ \\
\hline
\end{tabular}

Values are expressed as mean \pm S.D.

Significance differenceis expressed at $p<0.05$ using one-way ANOVA test and LSD test.

Values which have different letters in each column differ significantly, while thedifference among those with similar letters completely or partially not significant

\section{Relative organs weight}

Data presented in Table (3) showed the effect of feeding Purslane, Chia, Garden Cress, and Seeds Mixture on relative organs weight (liver and kidney) for hepatotoxicity rats.Relative liver and 


\section{Samah A. El-Hashash, et al}

kidney weight values showed significant increase in control (+ve) group as compared with negative control group $(P<0.05)$. Supplemented diets with Purslane, Chia and Garden cress (5\%) showed significant decrease $(\mathrm{P}<0.05)$ when compared with control positive. The best result was found in rats fed on seeds mixture (5\%) that showed significant decrease as compared to the control positive rats.

Table (3)

Effect of feeding Purslane,Chia, Garden Cress seeds and Seeds Mixture on relative organs weight (liver and kidney )in rats.

\begin{tabular}{|c|c|c|c|}
\hline \multicolumn{2}{|r|}{ Parameters } & Liver \% & Kidney\% \\
\hline \multicolumn{2}{|c|}{$(-\mathrm{Ve})$ control } & $6.90 \pm .24^{\mathrm{d}}$ & $1.30 \pm .21^{b}$ \\
\hline \multirow{5}{*}{ 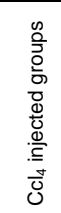 } & $(+\mathrm{Ve})$ control & $13.30 \pm 1.06^{\mathrm{a}}$ & $1.90 \pm .14^{\mathrm{a}}$ \\
\hline & Purslane Seeds & $8.10_{ \pm} .18^{\mathrm{b}}$ & $1.40 \pm .23^{\mathrm{b}}$ \\
\hline & Chia Seeds & $7.80 \pm .75^{\mathrm{bc}}$ & $1.20 \pm .23^{\mathrm{b}}$ \\
\hline & Garden Cress seeds & $7.40 \pm .39^{\mathrm{bcd}}$ & $1.50 \pm .20^{\mathrm{b}}$ \\
\hline & Seed mixture & $7.08 \pm .52^{\text {cd }}$ & $1.30 \pm .22^{\mathrm{b}}$ \\
\hline
\end{tabular}

Values are expressed as mean \pm S.D.

Significancedifference is expressed at $\mathrm{p}<0.05$ using one-way ANOVA test and LSD test.

Values which have different letters in each column differ significantly, while thedifference among those with similar letters completely or partially not significant.

\section{Biochemical Evaluations:}

\section{Liver functions:}

Data presented in Table (4) showed the effect of feeding Purslane, Chia, Garden cress and their Mixture on serum Aspartate amino transferase (AST) ,Alanine amino transferase (ALT), Alkaline phosphatase(ALP), and Total bilirubin (Bil) in $\mathrm{CCl}_{4}$-intoxicated rats. The mean values of AST, ALT, ALP and Bilin the (+ve) control group showed significant increase as compared to the (-ve) group. The rats received purslane, chia and garden cress seeds as a powder (5\%) showed significant decrease $(P<0.05)$ of all liver enzyme comparedto the $(+v e)$ controlgroup (table 4$)$. The best result was found in rats received mixture seeds $(5 \%)$.

Table (4)

Effect of feeding Purslane, Chia, Garden cress and Seeds Mixture on serum(aspartate amino transferase and alanine amino transferase, Alkaline phosphatase, and Total bilirubin) in rats

\begin{tabular}{|c|c|c|c|c|c|}
\hline \multicolumn{2}{|r|}{ Parameters } & AST (IU/L) & $\begin{array}{l}\mathrm{ALT} \\
\text { (IU/L) }\end{array}$ & $\begin{array}{l}\text { ALP } \\
\text { (IU/L) }\end{array}$ & $\begin{array}{c}\text { BIL } \\
\text { (IU/L) }\end{array}$ \\
\hline \multicolumn{2}{|c|}{ (-ve) Control } & $55.8 \pm 6.8^{\mathrm{c}}$ & $23.8 \pm 4.2^{d}$ & $82.5 \pm 14.9^{d}$ & $.39 \pm .12^{\mathrm{C}}$ \\
\hline \multirow{5}{*}{ 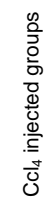 } & (+ve) Control & $206.5 \pm 32.8^{a}$ & $58 \pm 6.2^{\mathrm{a}}$ & $206.1 \pm 1.6 .1^{\mathrm{a}}$ & $.87 \pm .09^{\mathrm{a}}$ \\
\hline & Purslane Seeds & $80.5 \pm 7.7^{b}$ & $35.5 \pm 4.5^{\mathrm{bc}}$ & $125.6 \pm 5.31^{b}$ & $.57 \pm .05^{\mathrm{b}}$ \\
\hline & Chia Seeds & $83.1 \pm 7.1^{b}$ & $38 \pm 5.3^{b}$ & $106.8 \pm 8.8^{c}$ & $.62 \pm .06^{\mathrm{b}}$ \\
\hline & Garden cress Seeds & $84.3 \pm 8.1^{b}$ & $37.1 \pm 5.6^{\mathrm{bc}}$ & $100.5 \pm 10.07^{\mathrm{C}}$ & $.59 \pm .06^{b}$ \\
\hline & Seed Mixture & $66.3 \pm 7.4^{\mathrm{bc}}$ & $31.1 \pm 4.6^{\mathrm{C}}$ & $82.6 \pm 6.8^{d}$ & $.42 \pm .11^{\circ}$ \\
\hline
\end{tabular}

Values are expressed as mean \pm S.D.

Significance difference is expressed at $\mathrm{p}<0.05$ using one-way ANOVA test and LSD test.

Values which have different letters in each column differ significantly, while the difference among those with similar letters completely or partially not significant.

\section{Serum Albumin, Globulin and Total protein}

Data presented in Table (5) showed the effect of feeding Purslane, Chia, Garden cress and their Mixture on serumTotal protein, albumin and Globulin and in $\mathrm{CCl}_{4}$-intoxicated rats. The mean values of total protein, albumin and globulin in the (+ve) control group showed significant decrease compared to the (-ve) control group. The rats that received purslane, chia and garden cress seeds as a 


\section{Egypt. J. of Nutrition and Health Vol. 15 No. 1 January (2020)}

powder $(5 \%)$ showed significant increase $(\mathrm{P}<0.05)$ of total protein,albumin and globulin as compared tothe (+ve) control group as shown in table (5). The best result was found in rats that received seeds mixture (5\%).

Table (5)

Effect of feeding Purslane, Chia, Garden cress seeds and Seed Mixture on serum (Total protein, Albumin and Globulin) in rats .

\begin{tabular}{|c|c|c|c|c|}
\hline \multicolumn{2}{|c|}{$\begin{array}{ll}\text { Groups } & \text { Parameters }\end{array}$} & Total protein (g/dl) & Albumin (g/dl) & Globulin (g/dl) \\
\hline \multicolumn{2}{|c|}{ (-ve) Control } & $7.3 \pm .40^{\mathrm{a}}$ & $4.2 \pm .47^{\mathrm{a}}$ & $3.1 \pm .54^{\mathrm{a}}$ \\
\hline \multirow{5}{*}{ 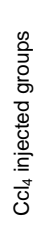 } & (+ve) control & $3.0 \pm .47^{\circ}$ & $1.3 \pm .25^{\mathrm{d}}$ & $1.7 \pm .43^{\mathrm{c}}$ \\
\hline & Purslane Seeds & $4.2 \pm .47^{b}$ & $2.1 \pm .27^{c}$ & $2.1 \pm .47^{\mathrm{b}}$ \\
\hline & Chia Seeds & $5.7 \pm .30^{\mathrm{b}}$ & $3.5 \pm .14^{b}$ & $2.2 \pm .63^{\mathrm{b}}$ \\
\hline & Garden cress & $5.8 \pm .31^{\mathrm{b}}$ & $3.3 \pm .35^{\mathrm{bc}}$ & $2.5 \pm .91^{\mathrm{b}}$ \\
\hline & Seed Mixture & $6.2 \pm .17^{\mathrm{a}}$ & $3.1 \pm .24^{c}$ & $3.1 \pm .47^{\mathrm{a}}$ \\
\hline
\end{tabular}

Values are expressed as mean \pm S.D.

Significancedifference is expressed at $\mathrm{p}<0.05$ using one-way ANOVA test and LSD test.

Values which have different letters in each column differ significantly, while thedifference among those with similar letters completely or partially not significant.

\section{Serum lipid profile:}

Data presented in Table (6) showed the effect of feedingPurslane , Chia , Garden cress seeds and Seeds Mixture on serum Cholesterol, Triglyceride ,high-density lipoprotein, low-density lipoprotein,Very low-density lipoprotein in $\mathrm{CCl}_{4}$-intoxicated rats. The mean values of cholesterol and triglyceride were significantly increased in the (+ve) control rats compared with the (-ve) control group . All supplemented diets with purslane, chia and garden cress seeds powder(5\%)showed significant decrease $(\mathrm{P}<0.05)$ comparing with the $(+v e)$ control rats. The best result was obtained in rats fed on seeds mixture $(5 \%)$.

The mean values of HDL were low in the (+ve) control group compared with the (-ve) control rats. All supplemented diets with purslane, chia and garden cress seeds powder(5\%)showed significant increase $(\mathrm{P}<0.05)$ compared with the $(+v e)$ control rats. The best result was obtained in rats fed on seeds mixture (5\%). the mean values of LDL were significantly increased in the $(+v e)$ control rats compared with the (-ve) control group. All supplemented diets with purslane, chia and garden cress seeds powder $(5 \%)$ lowered the level of $\operatorname{LLL}(\mathrm{P}<0.05)$ compared with the $(+\mathrm{ve})$ control rats. The best result was found in rats fed on seeds mixture (5\%). The mean value of VLDL in the (+ve) control was significantly higher than the (-ve) control group. The rats that received diets supplemented with purslane, chia and garden cress seeds powder $(5 \%)$ showed significant decrease $(P<0.05)$ compared with the $(+v e)$ control rats. The best result was obtained in rats fed on seeds mixture $(5 \%)$. 


\section{Table (6)}

Effect of feeding Purslane, Chia, Garden cress seeds and Seeds mixture on serum (Cholesterol , Triglyceride ,high-density lipoprotein , low-density lipoprotein and Very low-density lipoprotein ) in rats .

\begin{tabular}{|c|c|c|c|c|c|c|}
\hline \multicolumn{2}{|c|}{ Groups $\quad$ Parameters } & Chol. (mg/dl) & $\mathrm{T} . \mathrm{G}(\mathrm{mg} / \mathrm{dl})$ & $\mathrm{HDL}(\mathrm{mg} / \mathrm{dl})$ & LDL (mg/dl) & $\operatorname{VLDL}(\mathrm{mg} / \mathrm{dl})$ \\
\hline \multicolumn{2}{|r|}{ (-ve) Control } & $88.1 \pm 7.7^{\mathrm{c}}$ & $132 \pm 9.1^{c}$ & $49.1 \pm 4.7^{\mathrm{a}}$ & $12.6 \pm 6.9^{c}$ & $26.5 \pm 1.8^{\mathrm{c}}$ \\
\hline \multirow{5}{*}{ 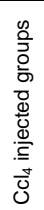 } & (+ve) control & $238 \pm 12.8^{a}$ & $238 \pm 12.8^{\mathrm{a}}$ & $33.1 \pm 2.6^{c}$ & $157.3 \pm 11.2^{\mathrm{a}}$ & $47.6 \pm 2.5^{\mathrm{a}}$ \\
\hline & Purslane Seeds & $118.9 \pm 13.3^{b}$ & $174.3 \pm 4.5^{\mathrm{b}}$ & $45.0 \pm 4.7^{b}$ & $39.1 \pm 14.7^{b}$ & $34.8 \pm .98^{\mathrm{b}}$ \\
\hline & Chia Seeds & $123.7 \pm 12.1^{b}$ & $179.5 \pm 4.6^{b}$ & $47.0 \pm 4.8^{\mathrm{ab}}$ & $40.8 \pm 15.3^{b}$ & $36.0 \pm .89^{\mathrm{b}}$ \\
\hline & Garden cress seeds & $131.3 \pm 6.5^{b}$ & $171.1 \pm 6.04^{\mathrm{b}}$ & $48.6 \pm 2.9^{\mathrm{ab}}$ & $48.5 \pm 5.1^{b}$ & $34.1 \pm 1.3^{b}$ \\
\hline & Seed Mixture & $98.5 \pm 5.4^{c}$ & $137.8 \pm 6.5^{\mathrm{C}}$ & $52.0 \pm 4.8^{\mathrm{a}}$ & $19.0 \pm 6.1^{c}$ & $27.5 \pm 1.3^{c}$ \\
\hline
\end{tabular}

Values are expressed as mean \pm S.D.

Significancedifference is expressed at $p<0.05$ using one-way ANOVA test and LSD test.

Values which have different letters in each column differ significantly, while thedifference among those with similar letters completely or partially not significant.

\section{Kidney functions :}

Data presented in Table (7) showed the effect of feeding Purslane, Chia , Garden cress seeds and their Mixture on kidney functions in the intoxicated rats. The mean values of urea, creatinine and uric acid the (+ve) control group revealed significant increase compared with the (-ve) control group. On supplementing diets withPurslane , Chia and Garden cress seeds induced (5\%) significant decrease $(\mathrm{P}<0.05)$ compared with the $(+\mathrm{ve})$ control rats. For all markers, the best results were noticed as a result of feeding seeds mixture (5\%). For serum urea, chia seeds -fed group showed also normal value,while garden cress seeds -fed group showed normal uric acid value.

Table(7)

Effect of feeding Purslane, Chia, Garden cress seeds and Seed mixture on kidney functions in rats.

\begin{tabular}{|c|c|c|c|c|}
\hline \multicolumn{2}{|c|}{ Parameters } & Urea (mg/dl) & Creatinine $(\mathrm{mg} / \mathrm{dl})$ & U.A (mg/dl) \\
\hline \multicolumn{2}{|r|}{ (-ve) control } & $21.17 \pm 3.06^{d}$ & $.70 \pm .06^{\circ}$ & $2.48 \pm .27^{\circ}$ \\
\hline \multirow{5}{*}{ 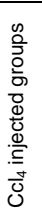 } & (+ve) control & $35.6 \pm 3.32^{\mathrm{a}}$ & $1.45 \pm .18^{\mathrm{a}}$ & $4.23 \pm .21^{\mathrm{a}}$ \\
\hline & Purslane Seeds & $27.8 \pm 2.31^{\mathrm{b}}$ & $.89 \pm .065^{\mathrm{b}}$ & $3.08 \pm .40^{\mathrm{b}}$ \\
\hline & Chia Seeds & $23.8 \pm 3.31^{\mathrm{cd}}$ & $.86 \pm .070^{\mathrm{b}}$ & $3.03 \pm .65^{b}$ \\
\hline & Garden cress Seeds & $26 \pm 4.19^{\mathrm{bc}}$ & $.86 \pm .073^{\mathrm{b}}$ & $2.93 \pm .33^{\mathrm{bc}}$ \\
\hline & Seed mixture & $20.83 \pm 2.7^{d}$ & $.73 \pm .037^{\circ}$ & $2.50 \pm .25^{\mathrm{c}}$ \\
\hline
\end{tabular}

Values are expressed as mean \pm S.D.

Significance is expressed at $\mathrm{p}<0.05$ using one way ANOVA test and LSD test.

Values which have different letters in each column differ significantly, while thedifference among those with similar letters completely or partially not significant

Lipids peroxidation malondialdehyde (MDA), nitric oxide (NO) and tumor necrosis factor -a in liver tissues.

Data presented in Table (8) showed the effect of feeding Purslane, Chia , Garden cress seeds and Seeds Mixture on lipids peroxidation malondialdehyde (MDA), nitric oxide (NO) and tumor necrosis factor $-\alpha(T N F-\alpha)$ in liver tissues of hepatotoxic rats. It could be noticed that positive control group recorded a significant increase $(p<0.05)$ in the mean value of MDA, NO and TNF- $\alpha$ compared with the negative control group.On supplementing the rats diet with purslane, chia, garden cress seeds and seeds mixture as a powder $(5 \%)$ the parameters showed significant decrease, $(P<0.05)$ compared with the (+ve)control rats. 


\section{Egypt. J. of Nutrition and Health Vol. 15 No. 1 January (2020)}

Table(8)

Effect offeeding Purslane , Chia, Garden cress seeds and Seed mixture on lipids peroxidation malondialdehyde, nitric oxide and tumor necrosis factor - $\alpha$ in liver tissues in rats.

\begin{tabular}{|c|c|c|c|c|}
\hline \multicolumn{2}{|c|}{$\begin{array}{ll}\text { Groups } & \text { Parameters } \\
\end{array}$} & $\mathrm{MDA}(\mathrm{mmol} / \mathrm{g})$ & $\mathrm{NO}(\mathrm{U} / \mathrm{g})$ & TNF- $\alpha(\mathrm{pg} / \mathrm{ml})$ \\
\hline \multicolumn{2}{|r|}{ (-ve) Control } & $0.15 \pm .010^{c}$ & $0.136 \pm .009^{C}$ & $0.14 \pm .018^{\mathrm{C}}$ \\
\hline \multirow{5}{*}{ 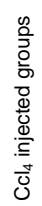 } & $(+v e)$ control & $0.27 \pm .007^{\mathrm{a}}$ & $0.35 \pm .004^{\mathrm{a}}$ & $0.27 \pm .007^{\mathrm{a}}$ \\
\hline & Purslane Seeds & $0.15 \pm .006^{c}$ & $0.17 \pm .007^{b}$ & $0.15 \pm .006^{c}$ \\
\hline & Chia Seeds & $0.17 \pm .003^{b}$ & $0.17 \pm .006^{\mathrm{b}}$ & $0.17 \pm .003^{\mathrm{b}}$ \\
\hline & Garden cress Seeds & $0.17 \pm .006^{b}$ & $0.17 \pm .011^{\mathrm{b}}$ & $0.17 \pm .006^{\mathrm{b}}$ \\
\hline & Seed mixture & $0.15 \pm .005^{c}$ & $0.14 \pm .006^{c}$ & $0.15 \pm .005^{\mathrm{C}}$ \\
\hline
\end{tabular}

Values are expressed as mean \pm S.D.

Significance is expressed at $\mathrm{p}<0.05$ using one way ANOVA test and LSD test.

Values which have different letters in each column differ significantly, while thedifference among those with similar letters completely or partially not significant

\section{Discussion}

Purslane , Chia and Garden cress seeds have a different phenolic compounds in different proportions such as Gallic ,Caffeine , Ellagic and coumarin. This agreed with the study Martínez and Paredes(2014) who showed that Caffeic acid is among the phenolic compounds already identified in chia products, and they play an important role in the prevention and management of different neurological disorders, such as epilepsy. Abd El azizet al., (2014) showed that purslane contain of phenolic compound fractionated to catechein, chlorogenic, salycillic and pyrogallol.Elagic resulted in maximum concentration of phenolic, followed by salicylic, chlorogenic and catechein. In addition to these results in agreement with Abd El Salamet al.,(2019) who showed The extract of (Garden Cress) GC seeds had high level of total phenols and total flavonoids. Gallic acid and hisperidin were the most abundant phenolic and flavonoid compounds in GC seed extract.

Injection by $\mathrm{CCl}_{4}$ is associated with reduced nutrient digestion and absorption as a result of low bile secretion and associated with loss of appetite leading to, leading to weight loss. Behboodiet al., (2017) showed that $\mathrm{CCl}_{4}$ caused significant reduction infeed intake and body wight gain .Feeding on Purslane, Chia and Garden cress seeds with the rats diet injected with $\mathrm{Ccl}_{4}$ which induced hepatotoxicity, led to significant increase in feed intake, body weight gain and efficiency ratio of rats. These results in agreement with Akramet al.,(2014) who studied the effect of purslane ethanolic extract administration on the body weightsof $\mathrm{CCl}_{4}$-treated rats. The results were the body weights of the rats significantly decreased in the $\mathrm{CCl}_{4}$-treated group, but increased in the normal control and purslane extract-treated groups. Also results are in agreement with Poudyal et al., (2012) who showed the intake of chia seeds by the Wistar ratsimprove the food consumption and body weight. Also results are in agreement with Abuelgasimet al., (2008) who demonstrated the protective ability of seed extracts of Lepidium sativumon liver injury induced by $\mathrm{Ccl}_{4}$. The anorexic effect produced by $\mathrm{Ccl}_{4}$ due to its hepatotoxicity was masked by the use of Lepidium sativum.

The marked increase in relative liver and kidney weights in $\mathrm{CCl} 4$-treated group which was reversed by supplementation with antioxidant sources, as in the present study, is in harmony with Akramet al., (2014) who noticed marked elevations in organ weights in $\mathrm{CCl}_{4}$-treated groups. These elevations were reversed by administration with purslane extract.Also results agreed with Bárbara et al., (2016) who found that Chia seeds decreased the percentage of liver fat and liver weights due to lower accumulation of lipids in the body, which may have led to increased excretion of fat in the feces, 


\section{Samah A. El-Hashash, et al}

since animals fed with chia showed an increase in fecal weight compared to the control one. Shukla and Bigoniya (2013) showed hepatoprotective effect of Lepidium Sativum Linn (Cruciferae) by reducing the liver weight of $\mathrm{CCl}_{4}$ intoxicated rats.

$\mathrm{CCl}_{4}$-induced liver injury is the best-characterized model of xenobiotic-induced hepatotoxicity(Brautbarand Williams, 2002; Brent and Rumack, 1993). The bio-activation of $\mathrm{CCl}_{4}$, primarily through the activity of CYP2E1, generates the free radicals ${ }^{\circ} \mathrm{CCl}_{3}$ and $\mathrm{CCl}_{3} \mathrm{OO}$, which results in hepatic damage. These free radicals initiate lipid peroxidation by abstracting a hydrogen atom from the polyunsaturated fatty acid of a phospholipid (Recknagelet al., 1989; Weber et al., 2003). The $\mathrm{CCl}_{4}$-induced lipid peroxidation in turn increases the permeability of plasma membrane to $\mathrm{Ca}^{2+}$, leading to severe disruption of calcium homeostasis and necrotic cell death (Weber et al., 2003). The extent of hepatic damage is assessed by the increase in serum levels of the cytoplasmic enzymes AST, ALT, ALP,Bil and by histopathological examination. The increased serum levels of AST and ALT have been attributed to damages in the structural integrity of the liver, as these cytoplasmic enzymes are released into circulation after cellular damage (Recknagelet al., 1989) Elevation of AST has been reported to be an index of hepatocellular injury in rats, whereas ALT elevation is more commonly associated with the necrotic state (Navarro and Senior, 2006). Serum ALP and GGT, which are important enzymes for assessing obstructive liver injury (Bulleet al., 1990; Kaplan, 1986), were also found to be significantly elevated in $\mathrm{CCl}_{4}$-treated rats. ALP activity is related to the functioning of hepatocytes. Suppression of increased ALP activity is indicative of the stabilization of biliary dysfunction in rat liver during chronic hepatic injury induced by $\mathrm{CCl}_{4}$ (Mukherjee, 2002). The increase in serum total bilirubin in $\mathrm{Ccl}_{4}$ treated rats may be owing to blockage of bile ductules as a result of the inflammation and fibrosis in the portal triads and/ or due to regurgitation of conjugated bilirubin from the necrotic hepatocytes to sinusoids (Ahmed, 2001).

All supplemented diet with purslane, chia and garden cress seeds in the present study decrease liver enzyme including transaminases (ALT and AST), alkaline phosphatase (ALP) and total bilirubin of rats injected with $\mathrm{ccl}_{4}$. These results are in agreement with Vogel(2002) who reported that treatment with purslane extract restored the liver enzymes to near normal level indicating protection against liver damage.

Elkhayatet al., (2008) found that $70 \%$ alcohol extract of $P$. oleracea significantly restored the hepatic marker enzymes and total bilirubin in hepatic injured rats to near-normal values.Ahmida (2010)reported that the hepato protective effective effect of portulaca oleracea was due to the phytochemical present in it, including omega-3-fatty acids, $\beta$-carotene, flavonoids and alkaloids. Rafaela et al.,(2015) confirmed that the consumption of white and black chia seeds was found to be effective for reducing liver damage and improvement in liver function. Sheisaet al.,(2019)attributed these effects to itscontent of high level of omega-3 fatty acids. Additionally,another substance that has been found to improve both lipids and liver enzymes is a-linolenic acid. This substance is present at high levels in chia seeds, ranging from 14 to $20 \mathrm{~g} / 100 \mathrm{~g}$ (55 to 65.8\%)Heinze et al.,(2012).The antioxidant in chia seeds such as Caffeic and Chlorogenic acid can improve both lipids and liver enzymes Kweonet al., (2001). On the other hand,Abaelgasimet al., (2008)found that the use of seed extracts of Lepidium sativum protect the liver from damage and improved histologic picture and biochemical markers of liver damage.The $\mathrm{Ccl} 4$ induced hepatotoxicity produced in rats leading to hepatic injury triggers the generation of toxic radicals which can be masked by using a correct antioxidant in adequate amount. The mechanism of the hepatoprotective action of the plant may be related to the ability of the plant to inhibit lipid peroxidation in the liver. The presence of flavanoids triterpens, alkaloid, tannin and coumarins in Lepidium sativum explain its role in hepatoprotection by 


\section{Egypt. J. of Nutrition and Health Vol. 15 No. 1 January (2020)}

inhibiting the free radicals mediated damage.Moreover, the improvement in liver functions markers status in seeds-fed groups, in the present study, may be attributed to the presence of not onlyphenolic compounds, but also dietary fibers and polyunsaturated fatty acids.

Feeding on diet supplemented purslane, chia and garden cress seeds in the present study , led to significant increase in serum total protein, albumin and globulin of rats injected with $\mathrm{ccl}_{4}$ that induced hepatotoxicity. These findings are in agreement with Anushaet al., (2011) showed the hepatoprotective effect of Portulaca oleracea $(P$. oleracea) by significantly restoring the levels of serum enzymes to normal and increase in albumin and total protein . $\mathrm{CCl}_{4}$ impaired protein metabolism in the injured hepatocytes causing a release of non-protein and protein nitrogenous substances. This is associated with a decrease in the level of protein synthesis along with an increase in the activities of hepatic enzymes Anusha et al., (2011). The ability of purslane extract to restore the levels of TP, Alb might be due to its effect on the functional statues of the poisoned liver and to protect against hepatotoxicity.Zamzamiet al., (2019) evaluated the hepatoprotective efficacy of $L$. sativum seeds in white male New-Zealand rabbits. The results revealed that treatment of rabbits administered with $\mathrm{CCl}_{4}$ with $L$. sativum seeds significantly repaired their liver injurious marker enzymes as well as bilirubin, total protein, and albumin, hence approving its hepatoprotective effect. Lepidium sativum improved the degree of structural damage and reduced inflammatory infiltration in hepatic cells. Balgoon(2019) assessed the protective role of Salvia officinalis essential oil (SO) against carbon tetrachloride $\left(\mathrm{CCl}_{4}\right)^{-}$ induced liver and kidney damage in mice.The activity of SO was associated with increasing total protein, albumin, globulin, and prothrombin. $\mathrm{SO}$ is a potential candidate for counteracting hepato/renal injury associating $\mathrm{CCl}_{4}$.

Feeding on purslane, chia and garden cress seeds in the present study, led to significant decrease in triglycerides, LDLc, VLDLc and significant increase in HDLc of rats injected with $\mathrm{CCl} 4$ induced hepatotoxicity conducted by Gatrehet al., (2011), they found that The serum levels of LDL-C, and TG decreased significantly in purslane group. All the therapeutic values of purslane ( $P$. oleracea) are attributed to the presence of many biologically active compounds including flavonoids, Alkaloids, Coumarins, and high content of $\omega-3$ fatty acids were considerable beneficial in preventing heart attacks and strengthening the immune system Okafor and Ezejindu (2014). Predominantly containing polyunsaturated (omega-3) fatty acids, make purslane medicinal plant to have favorable effects on cholesterol and triglyceride levels Yokoyamaet al., (2007).

Also results agree with Ricardo and Wayne (2005) who assessed the effect chia seed, which is the highest vegetative source of a-linolenic fatty acid, has on plasma total cholesterol, high-density lipoprotein (HDL), low-density lipoprotein(LDL), triacylglycerol content(T.G), and fatty acid profile when fed to rats. They found that the chia diets dramatically decreased triacylglycerol (T.G) levels, (LDL) level ,cholesterol and increased HDL and omega -3 fatty acid contents in rat serum. These findings suggest that a-linolenic-rich chia may be an alternative to omega-3 sources for vegetarians and people allergic to fish and fish product.Amawi andAljamal ( 2012) showed that the administration of Lepidium sativumimproved lipid profile in hypercholesterolemic rats.

Supplementing rat diet with purslane, chia and garden cress seeds in the present study, led to a marked improvement in the kidney function abnormalized by $\mathrm{CCl}_{4}$ injection evidenced better levels of urea, creatinine and uric acid. These results agreed with AbdAlah et al.,(2018)who investigated the effect of Purslane on kidney failure affected by copper toxicity in a rat model. They found thatPurslane administration decreased the elevated level of creatinine and BUN in rats which received toxic levels of copper due to its antioxidant and anti-inflammatory properties. The results agreed with Fahmy et 


\section{Samah A. El-Hashash, et al}

al.,(2018) who ensured the protective role of Salvia officinalis essential oil (SO) against carbon tetrachloride $\left(\mathrm{CCl}_{4}\right)$-induced liver and kidney damage in mice. The effect may occur via the antioxidant defense mechanism which in part related to the complexity of its chemical constituents. Also the result agreed with Loay and Wurood (2019) who reported that the ethanolic extract of garden cress has both renal protective and curative effects as it significantly reduced the blood levels of urea and creatinine which indicates increased glomerular filtration rate. In the present study rats diet supplemented with purslane,chia and garden cress seeds singly or as a mixture, led to significant decrease in lipids peroxidation and inflammation as manifested by decrease malondialdehyde (MDA) ,nitric oxide and TNF-a levels in liver tissues of rats. These findings were in line with Dkhil et al., (2011) who evaluated the anti- oxidative effects of (Portulaca oleracea) PO in adult male Waster albino rats. The results revealed that oral administration of PO improved liver and kidney functions. The improvement in all the indicators may be attributed to the presence of phenolic compound,which possess anti-oxidant, antidiabetic and anti-inflammatory activities $P O$ is the main source of anti-oxidant vitamins such as $\alpha$ tocopherol, ascorbic acid, $\beta$-carotene and glutathione. Bárbaraet al., (2016) investigated the influence of chia consumption on inflammation and oxidative stress in adult female ovariectomized rats fed a high-fat diet. Chia intake improved the antioxidant activity by increasing SOD expression, PPAR- $\alpha$ expression and catalase activity. In addition, chia consumption decreased the concentrations of the inflammatory markers IL-1 $\beta$. The improvement in all the indicators may be attributed to the presence of phenolic compounds, vitamins, minerals, dietary fiber, and polyunsaturated lipids.( Silvaet al.,2017)

Oliveira et al.,(2017) found that Chia intake increased catalase activity in the standard diet probably due to compounds present in the seeds including phenolic compounds and antioxidants. The main phenolic compounds found in chia are rosmarinic acid, quercertin, myricetin, kaempferol, caffeic acid, and galic acid. These compounds provide benefits to the human body due to the presence of hydroxyl groups that are readily oxidized to produce the corresponding $O$-quinones, which are effective scavengers of reactive oxygen species. Phenolic compounds can also alter the recruitment of inflammatory cells, decreasing the production of pro-inflammatory mediators. (Fraga, et al 2010). Mazin et al., (2019) evaluated the hepatoprotective efficacy of $L$. sativum seeds in white male NewZealand rabbits. The results revealed that concurrent treatment of rabbits administered with $\mathrm{CCl}_{4}$ for 5 and 10 weeks with $L$. sativum seeds significantly reduction of lipid peroxidation and repaired the antioxidant enzymatic status and total protein restoring them to normal levels. The hepatoprotective action of L. sativum seeds could be due to down regulation of cytokines [TNF- $\alpha$ and interleukin-6 (IL-6)] and stress gene [inducible nitric oxide synthase (iNOS) and HO-1] messenger ribonucleic acid (mRNA) expression. Lepidium sativum ethanolic extract pre protection also improved the degree of structural damage and reduced inflammatory infiltrationin hepatic cells. These outcomes established that Lepidium sativum ethanolic extract alleviates hepatic impairments and structural injury through the decay ofoxidative stress, inflammation, and apoptosis in the liver (Raishet al., 2016).

\section{Conclusion}

According to the results obtained in the present study, it appears that supplementing diet with purslane, chia and garden cress seeds singly or as amixture alleviated liver abnormalities and dysfunction associated with oxidative stress in liver tissues of $\mathrm{CCl}_{4}$-intoxicated rats. 


\section{Egypt. J. of Nutrition and Health Vol. 15 No. 1 January (2020)}

\section{References}

Abd-Allah, R.G. and Fereshteh, E. (2018):

Effect of Purslane on Kidney Failure Following Copper Toxicity in a Rat Model .J. of Iran Health Sci. 6( 1 ) : 25-32 .

Abd El Aziz, H. A. ;Ahmed,K.A. ;Abd El Hameed, A. K. (2014):

Chemical and remedial effects of purslane (portulaca oleracea) plant.Life Science Journal ;11(6):31-42

Abd EI Salam, K. H.; Toliba, A. and El-Nemr,S. (2019):

Chemical and functional properties of garden cress ( Lepidium sativum L.) seeds powder J. of Agricultural ResearchJ. Agric., 46 (5) :1517-1528.

Abuelgasim, A.I. ;Nuha, H.S. and Mohammed, A.H.(2008):

Hepatoprotective Effect of Lepidium sativum Against Carbon Tetrachloride Induced Damage in Rats . Journal of Animal and Veterinary Sciences;3: 20-23.

Ahmed, O. M. (2001):

Histopathological and biochemical evaluation of liver and kidney lesions in streptozotocin diabetic rats treated with glimepiride and various plant extracts. J.Union Arab Biol.; 16:585625 .

Ahmida, M.H. (2010):

Evaluation of in vivo antioxidant and hepatoprotective activity of portulaca oleracea L.against paracetamol induced liver toxicity in male rats. Am. J. Pharmagol.; 5:167-176.

Akram, E.; Pejman, M. ; Jalal, Z. ; Moghadam,A. and Parisa, M. (2014):

Hepatoprotective effects of Portulaca oleracea extract against CCl4-induced damage in rats . J. of Pharmaceutical Biology ; 53(7):1042-1051.

Allain , C. C. ; Poon , L. S. and Chan , C. S. (1974):

Enzymatic determination of serum total cholesterol . Clin. Chem. , 20 : 470-475.

Al-Sheddi, E.S.; Farshori, N.N.; Al-Oqail, M.M.; Musarrat, J.; Al-Khedhairy, A.A. and Siddiqui, M.A. (2016):

Protective effect of Lepidium sativum seed extract against hydrogen peroxide-induced cytotoxicity and oxidative stress in human liver cells (HepG2). Pharm. Biol.;54(2):314-321.

Amawi andAljamal (2012) :

Effect of Lepidium Sativum on Lipid Profiles and Blood Glucose in Rats. J. Phys. Pharm; 2(8): 277-281.

Anusha1,A. ; Venkateswarlu1,M. ; Prabhakaran, Ranganayakulu, D. (2011): Hepatoprotective activity of aqueous extract of Portulaca oleracea in combination with lycopene in rats . J. of Indian pharmacology ; 43(5): 563-567. 


\section{Samah A. El-Hashash, et al}

Ayerza, R. and Coates, W. (2011):

Protein content, oil content and fatty acid profiles as potential criteria to determine the origin of commercially grown chia (Salvia hispanica L.). Industrial Crop and Products, 34: 1366-1371.

Balgoon, M.J. (2019) :

Assessment of the Protective Effect of Lepidium sativum against Aluminum-Induced Liver and Kidney Effects in Albino Rat. Biomed Res. Int

Bárbara, p. S.; Desirrê, M. D. and Maria, E. ( 2016):

Chia Seed Shows Good Protein Quality, Hypoglycemic Effect and Improves the Lipid Profile and Liver and Intestinal Morphology of Wistar Rats . Plant Foods Hum. Nutr. ; 71:225-230.

Behboodi ,H.R.;Samadi, F.; Shams, M.; Ganji ,F. and Samadi, S. (2017):

Effects of Silymarin on Growth Performance, Internal Organs and Some Blood Parameters in Japanese Quail Subjected to Oxidative Stress Induced by Carbon Tetrachloride .J. of Poultry Science , 5 (1): 31-40.

Bigoniya, P. and Shukla, A. (2014):

Phytopharmacological screening of Lepidium sativum seeds total alkaloid: Hepatoprotective, antidiabetic and in vitro antioxidant activity along with identification by LC/MS/MS. Pharma Nutrition, 2(3):90.

Brautbar, N. and Williams, J. (2002):

Industrial solvents and liver toxicity: Risk assessment, risk factors and mechanisms. J. of Hyg. Environ Health 205:479-491.

Brent, J.A.and Rumack, B.H. (1993):

Role of free radicals in toxic hepatic injury. Clin Toxicol 31:173-196.

Bulle, F.; Mavier, P. and Zafrani, E.S. (1990):

Mechanism of gamma-glutamyl transpeptidase release in serum during intrahepatic and extrahepatic cholestasis in the rat: A histochemical, biochemical and molecular approach. Hepatology 11:545-550.

Capitani, M.I.; Spotorno, V.; Nolasco, S.M. and Tomás, M.C. (2012):

Physicochemical and functional characterization of by-products from chia (Salvia hispanica L.) seeds of Argentina. LWT - Food Science and Technology, 45: 94-102

Chan, K.; Islam, M.W.; Kamil, M.; Radhakrishnan, R.; Zakaria, M.N.; Habibullah, M. and Attas, A. (2000):

The analgesic and anti-inflammatory effects of Portulaca oleracea L. subsp. Sativa (Haw.) Celak. J. Ethno-pharmacol., 73:445-451

Chapman, D.G. ;Gastilla, R. and Campbell, T.A. (1959):

Evaluation of protein in food. I. A. Method for the determination of protein efficiency ratio .Can.j. Biochem. Physio. 1(37) 679- 686 


\section{Egypt. J. of Nutrition and Health Vol. 15 No. 1 January (2020)}

Chary, T. M. and Sharma, H. (2004):

Practical Biochemistry for Medical and Dental Students. Jaypee Brothers Medical Publishers (p)LTD, New Delhi. .

Coorey, R.; Grant, A. and Jayasena, V. (2012):

Effect of chia flour incorporation on the nutritive quality and consumer acceptance of chips. Journal of Food Research, 1: 85-95.

Del Valle Mendoza, J.; Pumarola, T.; Gonzales, L. A. and Del Valle, L. J. (2014):

Antiviral activity of maca (Lepidium meyenii) against human influenza virus. Asian Pac. J. Trop. Med., 7S1:S415-S420.

Dkhil, M.A.; Moniem ,A.E. ; Al-Quraishy, S. and Saleh, R.A. (2011):

Antioxidant effect of purslane (Portulaca oleracea) and its mechanism of action. J. of Med. Plant Res. ; 5(9):1589-93.

Drupt, F. (1974):

"Depression of human serum albumin." Farm. Boil., 9: 222-229.

Elkhayat, E.S.; Ibrahim, S.R. and Aziz, M.A. (2008):

Portulene, a new diterpene from Portulaca oleracea $L$. Asian Natural Products Research 10:1039-1043.

Fahmy, M. ; Diab, K. ; Abdel-Sami, N. ; Omara, E. A. (2018):

Carbon tetrachloride induced hepato/renal toxicity in experimental mice: antioxidant potential of Egyptian Salvia officinalis L essential oil " Environmental Science and Pollutio Research 25:27858-27876.

Faulkner N. R. and King, J. W. (1976):

Fundamental of Clinical Chemistry. 2 nd ed. Tietz Editor. Saunders Philadelphia. 994-998.

Fossati , P. ; Prencipe , L. and Berti , G. (1980):

Enzymatic colorimetric method for determination of uric acid in serum , 26(2):227-31.

Fraga , G. ; Galleano , M. ; Verstraiten, S. V. and Oteiza , P. (2010):

Mol. Aspects Med. ; 6 , 435 -445 CrossRef PubMed.

Friedwald , W. T. ; Leve , R. I. and Fredrickson , D. S. (1972):

Estimation of the concentration of low-density lipoprotein separated by three different methods. Cli. Chem.; 18: 499-502.

Gatreh, K. ; Farrokhi, E. ; Khalili, B. ; Rateian, M. and Moradi, M.(2011):

Purslane and lovastatin effects on serum araoxanase1 activity.J. of Shahrekord Univ. Med. Sci.; 13(1): 9-15.

Goupy, P. ;Hugues,M.; Biovin,P. and Amiot,M.J.(1999):

Antioxidant composition and activity of barley(Hordeum Vulgare) and malt extract and of isolated phenolic compounds.J.Sci.Food Agri., 79:1625-1634. 


\section{Samah A. El-Hashash, et al}

Green, L.C. ; Wagner, D.A. ; Glogowski, J. ; Skipper, P.L. ; Wishnok ,J.S. and Tannenbaum ,S.R. (1982):

Analysis of nitrate and nitrite and $(15 \mathrm{~N})$ nitrite in biological fluids. Anal Biochem .,126: 131138.

Heinze, C.R.; Hawkins, M.G.;Gillies, L.A.;Wu, X. and Walzem, R.L.(2012):

Effect of dietary omega-3 fatty acids on red blood cell lipid composition and plasma metabolites in the cockatiel, Nymphicushollandicus. J. of Anim. Sci. ; 90(9):3068-79.

Isin, Y.; Ismail, T.; Askim, H. and Tijen, D. (2007):

Salinity tolerance of (Portulaca oleracea L.) is achieved by enhanced antioxidative system, lower level of lipid peroxidation and proline accumulation. Environ. Exp. Bot., 61:49-57.

Ixtaina, V.Y.; Martínez, M.L.; Spotorno, V.; Mateo, C.M.; Maestri, D.M.; Diehl, B.W.K.; Nolasco, S.M. and Tomás, M.C. (2008):

Characterization of chia seed oils obtained by pressing and solvent extraction. Journal of Food Composition and Analyses, 24: 166-174.

Jayasekhar, P.; Mohanan, P. V. and Rahinam, K. (1997):

Hepatoprotective activity of ethyl acetate extract of Acacia catechu. Indian J. Pharmacol., 29:426-428.

Jin, R.; Lin, Z.J.; Xue, C.M. and Zhang, B. (2013):

An improved association-mining research for exploring Chinese herbal property theory: based on data of the Shennong's Classic of Materia Medica. J. Integr. Med., 11:352-365.

Kaplan, M.M. (1986):

Serum alkaline phosphatase-another piece is added to the puzzle. Hepatology 6:526528 [Google Scholar]

Karimi, G.; Hosseinzadeh, H. and Ettehad, N. (2004):

Evaluation of the gastric antiulcerogenic effects of Portulaca oleracea L. extracts in mice. Phytother. Res., 18:484-487.

Kweon, M. H.; Hwand, H. J. and Sung, H. C. (2001): Identification and antioxidant activity of novel chlorogenic acid derivatives from bamboo (Phyllostachys edulis). Journal of Agricultural and Food Chemistry. 49(10):4646-55.

Lee, A.S.; Lee, Y.J.; Lee, S.M.; Yoon, J.J.; Kim, J.S.; Kang, D.G. and Lee, H.S. (2012):

Portulaca oleracea ameliorates diabetic vascular inflammation and endothelial dysfunction in db/db mice. Evid. Based Complement. Alternat. Med., 2012:741-824

Liu, X.F.; Zheng, C.G.; Shi, H.G.; Tang, G.S.; Wang, W.Y.; Zhou, J. and Dong, L.W. (2015):

Ethanol extract from Portulaca oleracea $L$. attenuated acetaminophen-induced mice liver injury. Am. J. Transl. Res., 7:309-318. 


\section{Egypt. J. of Nutrition and Health Vol. 15 No. 1 January (2020)}

Loay, H. and Wurood, J. (2019):

The effect of Lepidium Sativum seeds extract on some oxidative stress, antioxidants and histological changes in rat treated with Ccl4 . Pak. J. Biotechnol. ; 16 (2) 145-151.

Lopes-Virella , M. F. ; Stone , S. ; Ellis , S. and Collwell , J. A. (1977) :

Cholesterol determination in high-density lipoprotein separated by three different methods .Clin. Chem. , $23(5): 882$.

Marineli, R.S.; Moraes, E.A.; Lenquiste, S.A.; Godoy, A.T.; Eberlin, M.N. and Maróstica-Jr, M.R. (2014):

Chemical characterization and antioxidant potential of Chilean chia seeds and oil (Salvia hispanica L.). LWT - Food Science and Technology, 59: 1304-1310.

Martínez-Cruz,A. and Paredes-López,G. (2014):

Phytochemical Profile and Nutraceutical Potential of Chia Seeds (Salvia Hispanica L.) by Ultra High Performance Liquid Chromatography.J. ChromatogrA.13:1346:1343

Mazin ,A. ; Zamzami, B. ; Othman, A. S. ; Baothman,A. Fatma, S. and Mohamed, K.A. (2019) : Amelioration of $\mathrm{CCl}_{4}$-Induced Hepatotoxicity in Rabbits by Lepidium sativum Seeds . p. 11-17.

Mukherjee, P.K. (2002):

Quality Control of Herbal Drugs, 1st ed. New Delhi: Business Horizons Pharmaceutical Publication, 531 [Google Scholar]

Naruse, K.; Tang, W.and Makuuchi M (2007):

Atrichia and bioarticials liver support: A review of perfusion treatment for hepatic failure patients. World J Gastroenterol.,13: 1516-1521.

Navarro, V.J.and Senior, J.R. (2006):

Drug related hepatotoxicity. J. of Engl. Med. ; 354:731-9

Ohkawa, H. ;Ohishi ,N. and Yagi, K.(1979):

Assay of lipid peroxidation in animal tissues by thiobarbituric acid reaction. Anal Biochem., 95:351-358

Okafor, I.A.; Ezejindu, D.N. (2014):

Phytochemical studies on Portulaca oleracea (purslane) plant.; 3(1): 132-136.

Oliveira, S. ;Vendramini,D.B.; Cazarin , A. ; Junior , J. P. ; Ferreira , A. B. ; Silva , M. A. and Bronze ,M.R. (2017):

Food Chem., 23(2):295 —305 CrossRef CAS PubMed .

Parry, O.; Marks, J.A. and Okwuasaba, F.K. (1993):

The skeletal muscle relaxant action of Portulaca oleracea: role of potassium ions. J. Ethnopharmacol., 40:187-194. 


\section{Samah A. El-Hashash, et al}

Parola, M.; Leonarduzzi, F. ;Biasi, M. ;Albano,E. Biocca, G. and Dianzani( 1992):

Vitamin E dietary supplementa-tion protects againstCcl ${ }_{4}$ induced chronic liver damage and cirrhosis. Hepatology, 16: 1014-1021.

Patton , M. ; Plante,I. ; Labrecque, G. ; Beauchamp, D. and Patton , C. J. and Crouch , S. R. (1977) :

Enzymatic colorimetric method for determination of urea in serum . Anal. Chem. , 49 : 464469 .

Poudyal, H. ; Panchal, S.K.; Waanders, J. ;Ward, L. and Brown, L. (2012):

Lipid redistribution by $\alpha$-linolenic acid-rich chia seed inhibits stearoyl-CoA desaturase- 1 and induces cardiac and hepatic protection in diet-induced obese rats. J. Nutr. Biochem. , 23:153-162.

Rafaela , M.D.; Carolina, M.D. and Érica, A.M. (2015):

Chia (Salvia hispanica L.) enhances HSP, PGC-1a expressions and improves glucose tolerance in diet-induced obese rats. J. of Nutrition, 31(5):740-748.

Raish, A. ; Ahmad, K. M. and Alkharfy, S. (2016):

Hepatoprotective activity of Lepidium sativum seeds against Dgalactosamine/lipopolysaccharide induced hepatotoxicity in animal model," BMC Complementary and Alternative Medicine; 16(1) : 501.

Recknagel, E. A.; Glende, J.r.; Dolak, J.A. and Waller,A.(1989):

Mechanisms of carbon tetrachloride toxicity. J.ofPharmacology \& Therapeutics, 43(1): 139_ 154

Reeves, P.G. ; Nielson, F.H. and Fahmy, J.H. (1993):

Reports of the American Institute of Nutrition, adhoc Willing Committee on Reformulation of AIN 93, Rodent diet. J. Nutri. 123: 1939-1951..

Reitman , S. and Frankel, S. (1957) :

A colorimetric method for the determination of serum glutamic oxaloacetic and glutamic pyruvic transaminases. Am. J. Clin. Path. , $28: 56$

Ricardo , A. and Wayne, C. (2005):

Ground chia seed and chia oil effects on plasma lipids and fatty acids in the rat .Nutrition Research25(11):995-1003.

Sallhab, M. and Canelo, R. (2011):

An overview of evidence-based management of hepatocellular carcinoma: A meta-analysis J. Cancer Res. Therapeut., 7(4): 463-475.

Saukkonen, J.; Cohn, D.L.; Jasmer, R.M.; Schenker, S. and Jereb, J.A. (2006) :

An Official ATS Statement: Hepatotoxicity of antituberculosis therapy. Am J Respir CritCare . 174: 935-952. 


\section{Egypt. J. of Nutrition and Health Vol. 15 No. 1 January (2020)}

Sheisa, C. S.; Beatriz ,C. S. and Hevelyse, M. C. (2019):

Antioxidant capacity and chemical composition in seeds rich in omega-3: chia, flax, and perilla. J. of Food Sci. Technol.

Shukla,A. and Bigoniya,p. (2013):

Hepatoprotective Effect of Lepidium Sativum Linn (Cruciferae) Total Alkaloid Fraction against $\mathrm{CCl} 4$ Induced Hepatotoxicity on Rats . J. of Pharmacognosy and Phytochemistry; 5(2): 94-99.

Silva , P. C. ; Anunciação, J. C. ; Silva, M. ; Della Lucia,C. and Pinheiro-Sant'Ana (2017):

Food Chem., 2017, 221, 1709-1716.

Snedecor, G. W. and Cochran, W. G. (1989):

Statistical Methods. 8th ed., lowa State University Press, Ames, lowa 50014, USA.

Sushmakumari, S.; Jaydeep, A.; Kumar, J. and Menon, V. (1989):

Effect of carnitine on malondialdehyde, taurine and glutathionelevel in heart rats subjected to myocardial stress by isoprotenol.Indian J. Exp. Biol., (27): 134-137.

Teixeira, M.C.; Carvalho, I.S. and Brodelius, M. (2010):

Omega-3 fatty acid desaturase genes isolated from purslane (Portulaca oleracea L.): expression in different tissues and response to cold and wound stress. J. Agric. Food Chem., 58:1870-1877.

Tetens, I (2009):

Opinion on the safety of "Chia seeds (Salvia hispanica L.) and ground whole Chia seeds" as a food ingredient. The European Food Safety Authority Journal, 996: 1-26.

Trinder,P.andAnn,S .(1969):

Enzymatic Colorimetric test with lipid clearing factor to determine triglycerides.Clin .Biochem .,6:24-27

Vogel ,H.G. (2002) :

Carbon tetrachloride induced liver fibrosis in rats. In: Vogel HG, Vogel WH, eds. Drug Discovery and Evaluation, Pharmacological Assays, 2nd ed. Berlin: Springer-Verlag, p. 942 .

Weber, L.W.;Boll, M. and Stampfl, A. (2003):

Hepatotoxicity and mechanism of action of haloalkanes: Carbon tetrachloride as a toxicological model. Crit. Rev. Toxicol 33:105-36 ..

Yokoyama, M.; Origasa, H.; Matsuzaki, M.; Matsuzawa, Y.; Saito, Y. and Ishikawa, Y.( 2007) : Effects of eicosapentaenoic acid on major coronary events in hypercholesterolaemic patients (JELIS): a randomisedopenlabel, blinded endpoint analysis J. of ancet.;370:220]. Lancet. 2007; 3(69):1090-1098. 


\section{Samah A. El-Hashash, et al}

Zamzami, M.A. ; Baothman, O.A. and Fatma, S. (2019):

Amelioration of CCl4-Induced Hepatotoxicity in Rabbits by Lepidium sativum Seeds."

Zhang, X.; Ji, Y.; Qu, Z.; Xia, J.C. and Wang, L. (2002):

Experimental studies on antibiotic functions of Portulaca oleracea L. in vitro. Chin. J. Microecol., 14:277-280.

\section{تأثير بذور بعض النباتات الطبية على التسمم الكبدى المحدث بواسطة رابع كلوريا

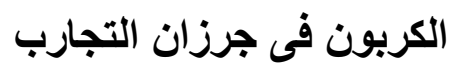

\section{سماح أحمد الحشاش ، أميرة مرسى المسلمانى ، اماتى على عبد المجيد الملخص العربى}

كثير من النباتات يتم استخدامها كنباتات طبية بواسطة كثير من الناس. نم اجراء هذه الدراسة لمعرفة تأثيربذور الرجلة

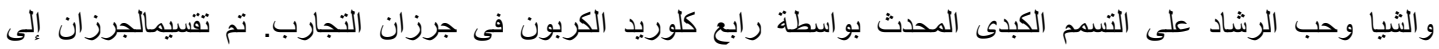

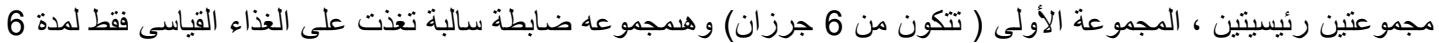

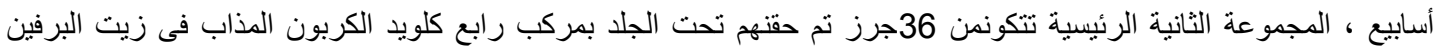

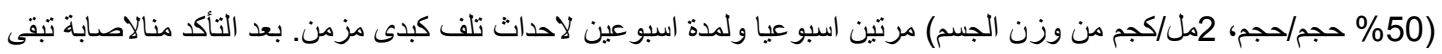
30 جرز مصاب تم تقسيمهم إلى 5 مجموعات منساوية العدد تشمل المجموعة الثانية و همجمو عة ظابطة موجبة تغذت على على الغذاء القياسى فقط ، و أما المجمو عات الأربعة الأخرى (الثالثة والر ابعة و الخامسة و السادسة) فقد نم تغذيتهم على الغذاء القياسى مضافا اليه مسحوق أى من بذور الرجلة، الثيا ، حب الرشاد أو خليطهم على الترتيب (بنسبة 5\%). استمرت مدة العلاج 4 أسابيع، وفى لإنى

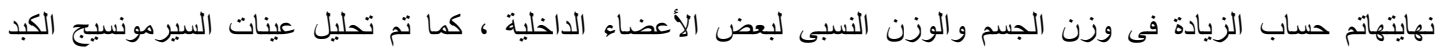

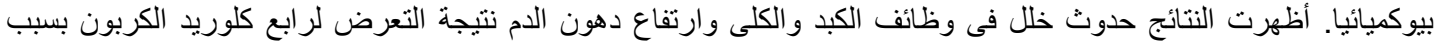
تأثيره المؤكسد. أدى استخدام بذور الرجلة و الثيا وحب الرشاد كلعلى حدة أو فى صورة خليط إلى تحسن ملحوظ فى وظائف الكبد و الكلى و انخفاض دهون الدم نتيجة لمحتواهم من المركبات الفينولية ومن ثم تأثير هم المضاد للأكسدة. وطبقا لهذه النتائج يمكن للمرضى الذين يعانون من تسمم الكبد نتيجة التعرض لمصادر رابع كلويد الكربون استخدام هذه البذور كل على حدة أو فى صورة

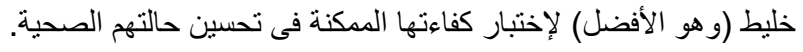

الكلمات المفتاحية: تسمم الكبد ـ رابع كلوريد الكربون - بذور الرجلة ـ بذور الثيا ـ بذور حب الرشاد ـ المركبات الفينولية ـ

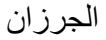

